\title{
Numerical and Experimental Study of CPU Cooling with Finned Heat Sink and Different P.C. Air Passages Configurations
}

\author{
Jalal M. Jalil \\ Electromechanical Eng. Dept. \\ University of Technology, \\ Baghdad, IRAQ \\ jalamjalil@gmail.com
}

Received: 02- Oct.-2017

http://doi.org/10.29194/NJES21010099

\author{
Ekbal H. Ali \\ Electromechanical Eng. Dept. \\ University of Technology, \\ Baghdad, IRAQ
}

\author{
Hiba H. Kurdi \\ Electromechanical Eng. Dept. \\ University of Technology, \\ Baghdad, IRAQ \\ hibakordy@yahoo.com
}

Revised: 29-Oct.-2017 Accepted: 18-Dec.-2017

\begin{abstract}
:
This study investigated numerically and experimentally fluid flow and heat transfer in the desktop PC. Three patterns of the positions of air inlet and outlet were tested to find the best one for cooling. The computer components in the present study are CPU, finned heat sink, power supply, motherboard, CD, HDD and fans. Three components which were generate heat are CPU, motherboard and power supply and there were two openings for air inlet and two for air outlet. The air inlet velocities were 1.2, 1.8, $2.4 \mathrm{~m} / \mathrm{s}$ with constant CPU fan velocity. The studied parameters were the changed of inlet air velocity, powers of CPU, motherboard and PSU and the positions of inlet air. The numerical results obtained are found in a good agreement with the experimental results. The experimental results show that the maximum temperature was $81^{\circ} \mathrm{C}$ at $16.5 \mathrm{~W}$ and $1.2 \mathrm{~m} / \mathrm{s}$. Numerical results showed that the CPU temperature reaches $89.6^{\circ} \mathrm{C}$ at 18.5 $\mathrm{W}$ and $1.2 \mathrm{~m} / \mathrm{s}$. From the results, it was found that; the temperatures of the main components (PSU and motherboard) affected little by CPU power and vice versa, the finned heat sink has higher cooling efficiency and the pattern 1 was the best pattern for CPU cooling.
\end{abstract}

Keywords: computational fluid dynamics, active heat dissipation, PC cooling, CPU cooling, finned heat sink, forced convection and electronic cooling.

$\begin{array}{ll}\begin{array}{l}\text { Nomenclature: } \\ \mathrm{h}_{\mathrm{HS}}\end{array} & \begin{array}{c}\text { Heat transfer coefficient for the air near } \\ \text { heat sink, } \mathrm{W} / \mathrm{m}^{2}{ }^{\circ} \mathrm{C}\end{array} \\ \mathrm{i}, \mathrm{j}, \mathrm{k} & \text { Unit vector in } \mathrm{x}-, \mathrm{y}-, \mathrm{z}-\text { direction } \\ & \text { respectively } \\ \mathrm{k}_{\mathrm{HS}} & \text { Thermal conductivity of motherboard, } \\ & \mathrm{W} / \mathrm{m}^{\circ} \mathrm{C} \\ \mathrm{PSU} & \text { Power supply unit } \\ \mathrm{MO} & \text { Motherboard } \\ \mathrm{HS} & \text { Heat Sink } \\ \mathrm{P}_{\mathrm{CPU}} & \text { CPU power, } \mathrm{W} \\ \mathrm{P}_{\mathrm{MO}} & \text { Motherboard power, } \mathrm{W} \\ \mathrm{P}_{\mathrm{PSU}} & \text { PSU power, } \mathrm{W}\end{array}$

$\mathrm{T}_{\infty} \quad$ Ambient temperature, ${ }^{\circ} \mathrm{C}$

$\mathrm{T}_{\text {air }} \quad$ Air (inside PC) temperature, ${ }^{\circ} \mathrm{C}$

$\mathrm{T}_{\mathrm{CPU}}$ CPU temperature, ${ }^{\circ} \mathrm{C}$

$\mathrm{W}_{\mathrm{CPU}}$ CPU fan velocity, $\mathrm{m} / \mathrm{s}$

$\mathrm{U}_{\text {in }}, \mathrm{V}_{\mathrm{in}}$ Inlet fan velocity in $\mathrm{x}, \mathrm{y}$ directions, $\mathrm{m} / \mathrm{s}$

$\mathrm{U}, \mathrm{V}, \mathrm{W}$ Velocities in $\mathrm{x}, \mathrm{y}, \mathrm{z}, \mathrm{m} / \mathrm{s}$

$\mu \quad$ Dynamic viscosity of fluid, $\mathrm{kg} / \mathrm{m} . \mathrm{s}$

$\rho \quad$ Density of fluid, $\mathrm{kg} / \mathrm{m}^{3}$

\section{Introduction:}

The CPU of the computer desktop must be cooled to the point of manufacture maximum allowable value, typical limit of CPU case ranging from $70^{\circ} \mathrm{C}$ to $85^{\circ} \mathrm{C}$ depending on different CPU packages. In the CPU cooling, heat sink was used. The heat was removed into air using fan which is attached to heat sink. There are several ways to supply the air to the heat sink, such as active heat sink, in this way small fan attached to the heat sink, and this method considered a best for cooling [1]. The rapid development of power electronics leads to processors with high power density. This leads to increased operating frequency and power consumption and decrease in sizes. At the same time, thermal solutions and better airflow become more limit within the same computer system. The result is the increasing importance of the system to make sure the thermal requirements of the system [3]. CPUs of the computers should cool to reduce the maximum operating temperature and remove heat generated by CPU. Although there are several methods for cooling, but that the common method is forced convection air-cooling. In this way heat removing directly, fan with heat sink is collected and placed on the CPU. Air is pushed through the heat sink by the fan. By this method, the heat is removed and transfer directly to the final medium, air [4]. The temperature problem in computer is continuous, this mean that the need for the CPU development, therefore cooling way is developed. For this reason, the study of computer desktop cooling needs more efficient cooling system.

Mohan and Govindarajan [5] studied CFD for forced air cooling using heat sink in PC, which used $80 \mathrm{~W} \mathrm{CPU}$, while this number shall be 
increase from $70 \mathrm{~W}$ to $120 \mathrm{~W}$. This study found optimum plate fin heat sink model and cylindrical plate fin heat sink model with changeable copper base to control the process of CPU heat sink. Chang, et al. [1] investigated the results of CFD analysis to cool 30-W CPU of a desktop PC with lower air flow rate and smaller heat sink size. This was done by using single fan air motion in the PC. Chiang, et al. 2005 [2] investigated the analysis of heat transfer of the components which generate heat with various positions of side fans (used two fans) in a 3D P.C. The CFD was applied for simulation of the heat dissipation in an opening box. The parameters were centered on, Reynolds number of the inlet and positions of the two fans on the side wall of P.C. . Wang et al. [6] found optimal shape for chassis heat dissipation in a passive fashion, by arranged the locations and directions of fans. It is concluded that optimal shapes in terms of heat dissipation of chip-based elements do exist with suitable conditions of the fan and openings. Maode et al. [7] studied the numerical simulation of temperature field on the motherboard by using thermal analysis software. From the results it appeared that the Northbridge, CPU and the display card have higher power consumption.

The present work studies the best pattern to enhance cooling efficiency in P.C. experimentally and numerically. The experimental study includes the effect of changing inlet air velocity, powers of heat generation components (CPU, motherboard and PSU) and three patterns with different inlet positions to enhance the cooling. The numerical study solves the main equations of continuity, momentum, energy for air and heat conduction for CPU, PSU, motherboard and finned heat sink.

\section{Mathematical and Numerical Analysis:}

Governing Equations (laminar flow):

For flow of air inside the PC, laminar 3-D, forced convection, steady, incompressible with Cartesian Coordinates. The Navier Stokes equations (continuity, momentum and energy) are as follows [8]:

Continuity equation

$\frac{\partial}{\partial x}(\rho u)+\frac{\partial V}{\partial y}(\rho v)+\frac{\partial W}{\partial z}(\rho w)=0 \ldots \ldots .(1)$

Momentum equation

U-Momentum (x-direction)

$\frac{\partial}{\partial \mathrm{x}}(\mathrm{uu})+\frac{\partial}{\partial \mathrm{y}}(\mathrm{uv})+\frac{\partial}{\partial \mathrm{z}}(\mathrm{uw})=-\frac{1}{\rho} \frac{\partial \mathrm{P}}{\partial \mathrm{x}}+$

$v\left(\frac{\partial^{2} \mathrm{u}}{\partial \mathrm{x}^{2}}+\frac{\partial^{2} \mathrm{u}}{\partial \mathrm{y}^{2}}+\frac{\partial^{2} \mathrm{u}}{\partial \mathrm{z}^{2}}\right)$

V-Momentum (y-direction)

$\frac{\partial}{\partial \mathrm{x}}(\mathrm{vu})+\frac{\partial}{\partial \mathrm{y}}(\mathrm{vv})+\frac{\partial}{\partial \mathrm{z}}(\mathrm{vw})=-\frac{1}{\rho} \frac{\partial \mathrm{P}}{\partial \mathrm{y}}+$

$v\left(\frac{\partial^{2} \mathrm{v}}{\partial \mathrm{x}^{2}}+\frac{\partial^{2} \mathrm{v}}{\partial \mathrm{y}^{2}}+\frac{\partial^{2} \mathrm{v}}{\partial \mathrm{z}^{2}}\right)$ $\frac{\partial}{\partial x}(w u)+\frac{\partial}{\partial y}(w v)+\frac{\partial}{\partial z}(w w)=-\frac{1}{\rho} \frac{\partial P}{\partial z}+$

$v\left(\frac{\partial^{2} \mathrm{w}}{\partial \mathrm{x}^{2}}+\frac{\partial^{2} \mathrm{w}}{\partial \mathrm{y}^{2}}+\frac{\partial^{2} \mathrm{w}}{\partial \mathrm{z}^{2}}\right)$

Energy equation

$\frac{\partial}{\partial \mathrm{x}}(\mathrm{uT})+\frac{\partial}{\partial \mathrm{y}}(\mathrm{vT})+\frac{\partial}{\partial \mathrm{z}}(\mathrm{wT})=\frac{\mathrm{k}}{\rho \mathrm{C}_{\mathrm{p}}}\left(\frac{\partial^{2} \mathrm{~T}}{\partial \mathrm{x}^{2}}+\frac{\partial^{2} \mathrm{~T}}{\partial \mathrm{y}^{2}}+\right.$

$\left.\frac{\partial^{2} \mathrm{~T}}{\partial \mathrm{z}^{2}}\right)$

The transport equations for continuity, momentum and energy all have the general form [9]:

$\frac{\partial}{\partial \mathrm{x}}(\rho \mathrm{u} \emptyset)+\frac{\partial}{\partial \mathrm{y}}(\rho \mathrm{v} \emptyset)+\frac{\partial}{\partial \mathrm{z}}(\rho \mathrm{w} \emptyset)=\frac{\partial}{\partial \mathrm{x}}\left(\Gamma_{\emptyset} \frac{\partial \emptyset}{\partial \mathrm{x}}\right)+$

$\frac{\partial}{\partial \mathrm{y}}\left(\Gamma_{\varnothing} \frac{\partial \emptyset}{\partial \mathrm{y}}\right)+\frac{\partial}{\partial \mathrm{z}}\left(\Gamma_{\varnothing} \frac{\partial \emptyset}{\partial \mathrm{z}}\right)+\mathrm{S}_{\emptyset}$

Where $\varnothing$ the dependent variable, and $S_{\varnothing}$ is the source term which has different expressions for different transport equations. Table (1) gives the expression for the source term $S_{\emptyset}$ for each dependent variable which is likely to be needed in solving fluid flow problems. The equations solved (by finite volume method CFD) with 1000 iteration at 15 minutes using Fortran 90 and TECPLOT.

Table 1 Source term in the transport equations for laminar flow

\begin{tabular}{|c|c|c|c|}
\hline Equation & $\emptyset$ & $\Gamma_{\varnothing}$ & $\mathrm{S}_{\varnothing}$ \\
\hline Continuity & 1 & 0 & 0 \\
\hline x-momentum & $\mathrm{U}$ & $v$ & $-\frac{\partial \mathrm{P}}{\partial \mathrm{x}}$ \\
\hline $\mathrm{y}$-momentum & $\mathrm{V}$ & $v$ & $-\frac{\partial \mathrm{P}}{\partial \mathrm{Y}}$ \\
\hline z-momentum & $\mathrm{W}$ & $v$ & $-\frac{\partial \mathrm{P}}{\partial \mathrm{Z}}$ \\
\hline Energy & $\mathrm{T}$ & $\alpha$ & \\
\hline
\end{tabular}

Where:

$\alpha=\frac{\mathrm{k}}{\rho \mathrm{C}_{\mathrm{p}}}$

\section{Steady Heat Conduction:}

The heat transfer within solid PC components is numerically calculated. The system is in a steady state, then the heat flow in the $\mathrm{x}, \mathrm{y}$ and $\mathrm{z}$ directions may be calculated from Fourier equation:

$$
\mathrm{q}=-\mathrm{kA} \frac{\partial \mathrm{T}}{\partial \mathrm{x}}
$$

Energy balance methods were used and can be described as the summation of heat in and out equals to zero and were applied over small elements, the element has six faces. These elements in heat generation components [10, 11 and 12]:
1. CPU.
2. PSU.
3. Motherboard.

And finned heat sink

For example; node details of finned heat sink as shown in Figs. 1 and 2 . The finned heat sink which connected with the CPU has eight fins, each fin has $(5 \times 1 \times 16)$ nodes and heat sink base 
has $(16 \times 15 \times 1)$ nodes, all fin nodes have two faces which has convection except the nodes in edge of fins, nodes on base in region with CPU has five faces of conduction one of these faces conduction with CPU and in the sixth face which opposite to it there is convection with air or conduction with fins.

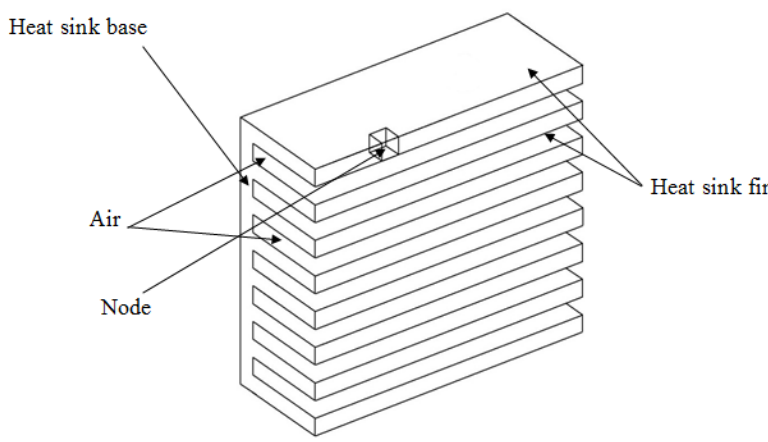

Figure 1: Heat Sink Node

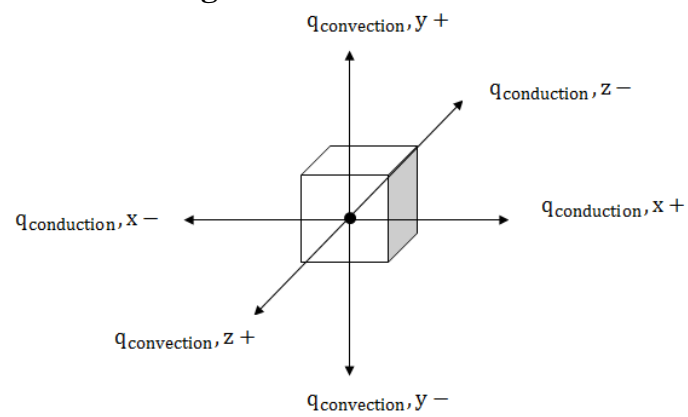

Figure 2: Energy balance for nodes on heat sink

$$
\begin{aligned}
& \sum \mathrm{q}_{\text {all faces }}= \\
& \sum \mathrm{q}_{\text {all faces }}=\mathrm{q}_{\mathrm{e}-\mathrm{x}}+\mathrm{q}_{\mathrm{w}-\mathrm{x}}+\mathrm{q}_{\mathrm{n}-\mathrm{y}}+\mathrm{q}_{\mathrm{s}-\mathrm{y}} \\
& +\mathrm{q}_{\mathrm{t}-\mathrm{z}}+\mathrm{q}_{\mathrm{b}-\mathrm{z}} \quad \ldots .(8) \\
& \mathrm{q}_{\mathrm{e}-\mathrm{x}}+\mathrm{q}_{\mathrm{w}-\mathrm{x}}+\mathrm{q}_{\mathrm{n}-\mathrm{y}}+\mathrm{q}_{\mathrm{s}-\mathrm{y}}+\mathrm{q}_{\mathrm{t}-\mathrm{z}}+\mathrm{q}_{\mathrm{b}-\mathrm{z}} \\
& =0 \quad \ldots \ldots(9) \\
& \mathrm{q}_{\mathrm{e}-\mathrm{x}}=\frac{-\mathrm{k}_{\mathrm{HS}} \mathrm{A}_{\mathrm{e}}}{\Delta \mathrm{x}}\left(\mathrm{T}_{\mathrm{HS}(\mathrm{i}, \mathrm{j}, \mathrm{k})}-\mathrm{T}_{\mathrm{HS}(\mathrm{i}+1, \mathrm{j}, \mathrm{k})}\right) \ldots \\
& \mathrm{q}_{\mathrm{w}-\mathrm{x}}=\frac{-\mathrm{k}_{\mathrm{HS}} \mathrm{A}_{\mathrm{w}}}{\Delta \mathrm{x}}\left(\mathrm{T}_{\mathrm{HS}(\mathrm{i}, \mathrm{j}, \mathrm{k})}-\mathrm{T}_{\mathrm{HS}(\mathrm{i}-1, \mathrm{j}, \mathrm{k})}\right) \text {... } \\
& \mathrm{q}_{\mathrm{n}-\mathrm{y}}=\mathrm{h}_{\mathrm{HS}} \mathrm{A}_{\mathrm{n}}\left(\mathrm{T}_{\mathrm{HS}(\mathrm{i}, \mathrm{j}, \mathrm{k})}-\mathrm{T}_{\text {air }}\right) \\
& \mathrm{q}_{\mathrm{s}-\mathrm{y}}=\mathrm{h}_{\mathrm{HS}} \mathrm{A}_{\mathrm{S}}\left(\mathrm{T}_{\mathrm{HS}(\mathrm{i}, \mathrm{j}, \mathrm{k})}-\mathrm{T}_{\text {air }}\right) \\
& \mathrm{q}_{\mathrm{t}-\mathrm{z}}=\mathrm{h}_{\mathrm{HS}} \mathrm{A}_{\mathrm{b}}\left(\mathrm{T}_{\mathrm{HS}(\mathrm{i}, \mathrm{j}, \mathrm{k})}-\mathrm{T}_{\mathrm{air}}\right) \\
& \mathrm{q}_{\mathrm{b}-\mathrm{z}}=\frac{-\mathrm{k}_{\mathrm{HS}} \mathrm{A}_{\mathrm{t}}}{\Delta \mathrm{z}}\left(\mathrm{T}_{\mathrm{HS}(\mathrm{i}, \mathrm{j}, \mathrm{k})}-\mathrm{T}_{\mathrm{HS}(\mathrm{i}, \mathrm{j}, \mathrm{k}-1)}\right) \text {. }
\end{aligned}
$$

The temperature is given by:

$$
\begin{array}{r}
\mathrm{T}_{\mathrm{HS}(\mathrm{i}, \mathrm{j}, \mathrm{k})}=\left[\mathrm{C}_{\mathrm{e}} \mathrm{T}_{\mathrm{HS}(\mathrm{i}+1, \mathrm{j}, \mathrm{k})}+\mathrm{C}_{\mathrm{w}} \mathrm{T}_{\mathrm{HS}(\mathrm{i}-1, \mathrm{j}, \mathrm{k})}\right. \\
+\mathrm{C}_{\mathrm{n}} \mathrm{T}_{\text {air }}+\mathrm{C}_{\mathrm{s}} \mathrm{T}_{\text {air }}+\mathrm{C}_{\mathrm{t}} \mathrm{T}_{\text {air }} \\
+\mathrm{C}_{\mathrm{b}} \mathrm{T}_{\mathrm{HS}(\mathrm{i}, \mathrm{j}, \mathrm{k}-1)] / \mathrm{C}} \ldots .(16)
\end{array}
$$

Where:

$\mathrm{C}_{\mathrm{e}}=\frac{\mathrm{k}_{\mathrm{HS}} \mathrm{A}_{\mathrm{e}}}{\Delta \mathrm{x}}, \mathrm{C}_{\mathrm{w}}=\frac{\mathrm{k}_{\mathrm{HS}} \mathrm{A}_{\mathrm{w}}}{\Delta \mathrm{x}}, \mathrm{C}_{\mathrm{n}}=\mathrm{h}_{\mathrm{HS}} \mathrm{A}_{\mathrm{n}}$,

$\mathrm{C}_{\mathrm{s}}=\mathrm{h}_{\mathrm{HS}} \mathrm{A}_{\mathrm{S}}, \mathrm{C}_{\mathrm{t}}=\mathrm{h}_{\mathrm{HS}} \mathrm{A}_{\mathrm{t}}$,

$$
\mathrm{C}_{\mathrm{b}}=\frac{\mathrm{k}_{\mathrm{HS}} \mathrm{A}_{\mathrm{b}}}{\Delta \mathrm{z}} \text {. }
$$

And

$$
\mathrm{C}=\mathrm{C}_{\mathrm{s}}+\mathrm{C}_{\mathrm{n}}+\mathrm{C}_{\mathrm{e}}+\mathrm{C}_{\mathrm{w}}+\mathrm{C}_{\mathrm{t}}+\mathrm{C}_{\mathrm{b}}
$$

\section{Experimental Apparatus:}

The experimental rig was constructed to study the fluid flow and heat transfer in box similar to the computer case. The idea of the study was to find the effect of changing the powers multicomponents (CPU, PSU, and motherboard) and the inlet air velocity and changing inlet positions. The photograph of experimental apparatus is shown in Fig. 3, which consists of:

1. Pyrex box: Have dimensions $(40 \times 40 \times 20 \mathrm{~cm})$ in $\mathrm{X}, \mathrm{Y}$ and $\mathrm{Z}$ directions.

2. Four heaters: used to represent CPU, PSU, and motherboard.

3. Heat sink: finned heat sink made from aluminum.

4. Fans: two fans for air inlet and one for CPU.

5. Voltage regulator (Variac).

6. DC power supply: to change the velocity.

7. Measurement units.

a. Temperature recorder.

b. Infrared thermometer (laser thermometer).

c. Hot wire anemometer.

d. Digital power clamp meter.

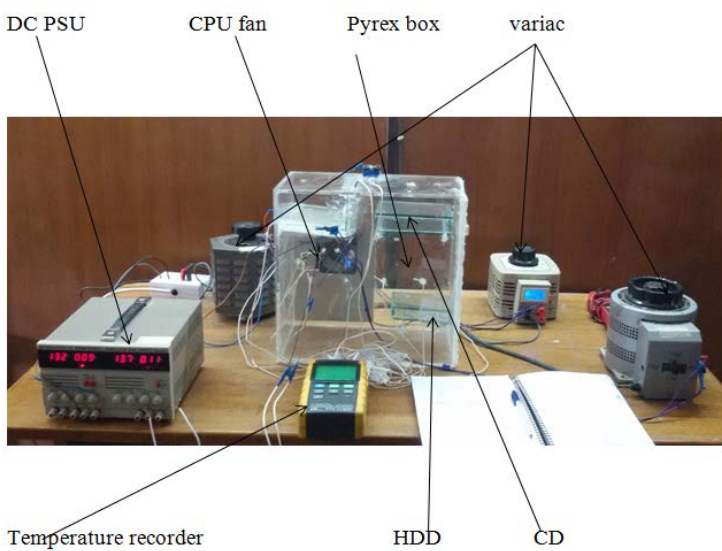

Figure 3: Photograph of experimental apparatus

\section{Results and Discussion:}

\section{Experimental Results:}

Three patterns were used in experiments for three positions of inlet as shown in Fig. 4. The inlets and outlets have the dimensions $(4 \times 4 \mathrm{~cm})$; these dimensions were chosen based on the previous references. The positions were chosen based on the previous references and to be near the heat sources so that the flow is directly on these sources. There were two fans at inlets using to change the velocity of air entry. 


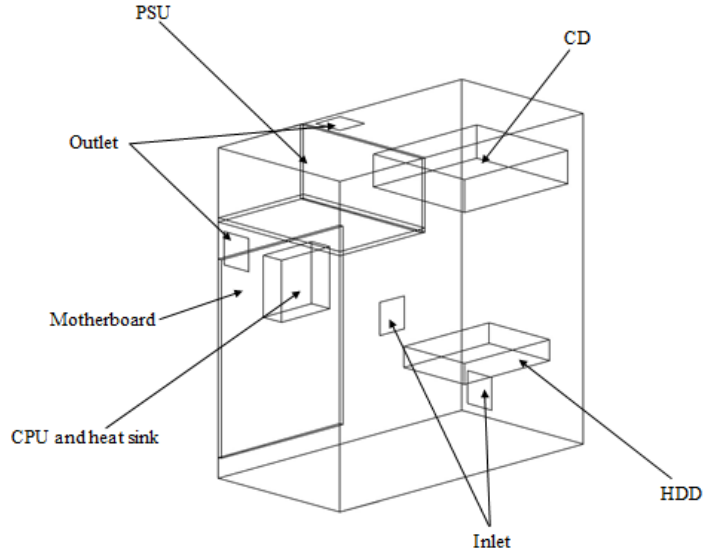

(a)
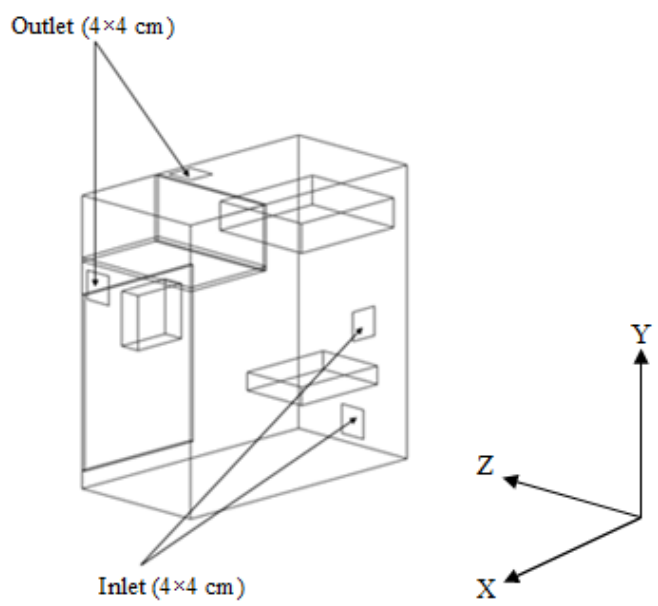

(b)

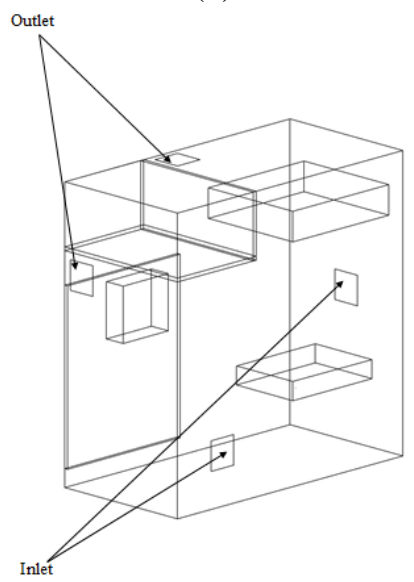

(c)

Figure 4: The schematic diagram of experimental apparatus (a. pattern 1, b. pattern 2, c. pattern 3)

\subsection{Pattern 1:}

\subsubsection{The Effect of Inlet Air Velocity:}

In this pattern, the first air inlet was below the HDD and the second in position opposite to the CPU and HS, the reason of these positions was to circulate the air in the area of HDD and CD, and the position of the second inlet was to keep the air across on CPU to cool it. Fig. 5 illustrates the variation of temperatures of the components with inlet velocity at $\mathrm{P}_{\mathrm{CPU}}=16.5 \mathrm{~W}, \mathrm{P}_{\mathrm{PSU}}=24 \mathrm{~W}$, $\mathrm{P}_{\mathrm{MO}}=12 \mathrm{~W}$. The temperature was decreased with increase the inlet velocity, the slope of decrease are similar for all components. The temperature of $\mathrm{CPU}$ is higher than the others, it various between $81^{\circ} \mathrm{C}$ at minimum inlet air velocity $1.2 \mathrm{~m} / \mathrm{s}$ to $76.4^{\circ} \mathrm{C}$ at $2.4 \mathrm{~m} / \mathrm{s}$. The $\mathrm{HS}$ temperature is the lowest one, it various between $44^{\circ} \mathrm{C}$ at minimum inlet air velocity $1.2 \mathrm{~m} / \mathrm{s}$ to $39.3^{\circ} \mathrm{C}$ at $2.4 \mathrm{~m} / \mathrm{s}$. The power of the components in this graph represents the maximum allowable powers to reach the temperature limits. The velocity of CPU fan was set at $4 \mathrm{~m} / \mathrm{s}$ for all experiments. The temperature of PSU will depends on the cooling; the lower face temperature is higher than the front face due to the position of the CPU fan was set to be collected with the finned heat sink. The temperatures of all components have the same behavior of the effect by the velocity and decrease or increase by about $2^{\circ} \mathrm{C}$.

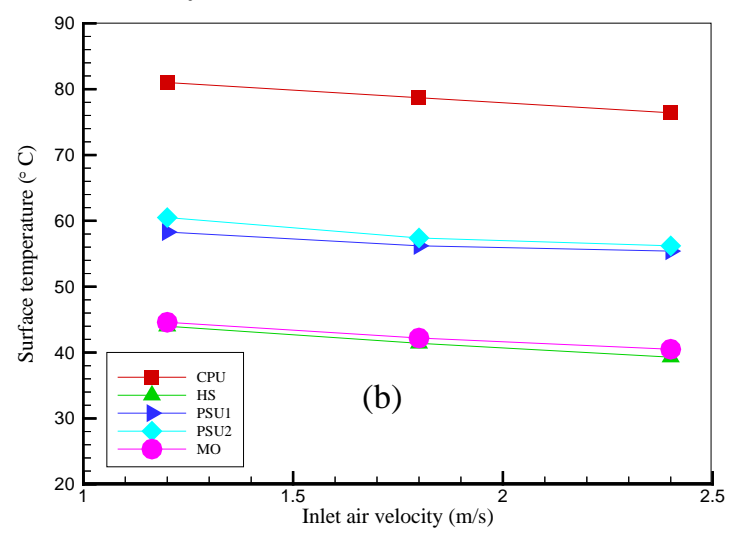

Figure 5: Variation of temperatures of the components with inlet velocity at $\mathrm{P}_{\mathrm{CPU}}=16.5 \mathrm{~W}$, $\mathrm{P}_{\mathrm{PSU}}=24 \mathrm{~W}, \mathrm{P}_{\mathrm{MO}}=12 \mathrm{~W}$, pattern 1

\subsubsection{The Effect of Power:}

In the first pattern, the effect of CPU power change was studied, Fig. 6 shows the variation of temperatures of the components with CPU power at inlet velocity $1.2 \mathrm{~m} / \mathrm{s}, \mathrm{P}_{\mathrm{PSU}}=24 \mathrm{~W}, \mathrm{P}_{\mathrm{MO}}=12 \mathrm{~W}$, the temperatures was increase with increase of CPU power, the slope of the increase of temperature components was similar for all components and different from the CPU slope. The temperature of CPU is higher than the others, it various between $59.3^{\circ} \mathrm{C}$ at $8.5 \mathrm{~W}$ and $81^{\circ} \mathrm{C}$ at $16.5 \mathrm{~W}$. HS temperature is the lowest one, it various between $40.7^{\circ} \mathrm{C}$ and $44^{\circ} \mathrm{C}$. The temperatures of CPU are greatly affected by the change of the CPU power, while the temperatures of other components are little affected. Fig. 7 shows the variation of CPU temperature with the variation of inlet air velocity, at $\mathrm{P}_{\mathrm{PSU}}=24 \mathrm{~W}$, $\mathrm{P}_{\mathrm{MO}}=12 \mathrm{~W}$, the slope of CPU temperature decrease was similar. The higher temperature was found at $1.2 \mathrm{~m} / \mathrm{s}$ and $16.5 \mathrm{~W}$, it is equal to $81^{\circ} \mathrm{C}$ 
and the lowest temperature at $2.4 \mathrm{~m} / \mathrm{s}$ and $8.5 \mathrm{~W}$, and it is equal to $55.2^{\circ} \mathrm{C}$.

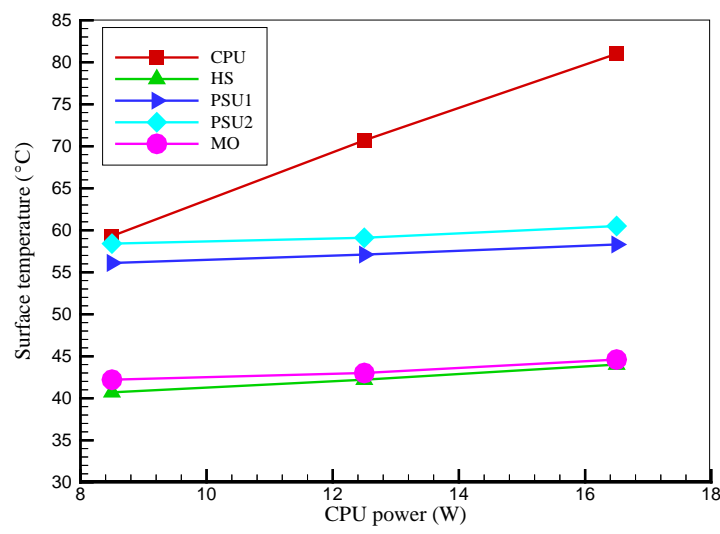

Figure 6: Variation of temperatures of the components with CPU power at inlet velocity 1.2 $\mathrm{m} / \mathrm{s}$ at $\mathrm{P}_{\mathrm{PSU}}=24 \mathrm{~W}, \mathrm{P}_{\mathrm{MO}}=12 \mathrm{~W}$.

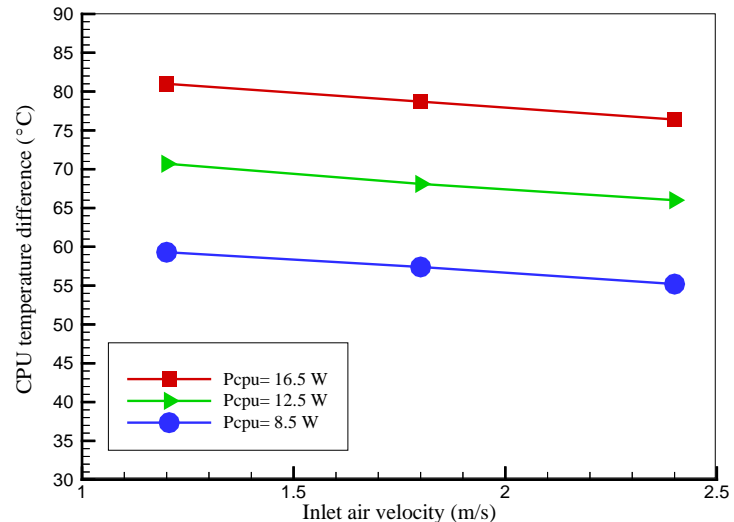

Figure 7: Variation of CPU temperature with the variation of inlet air velocity, at $\mathrm{P}_{\mathrm{PSU}}=24 \mathrm{~W}$, $\mathrm{P}_{\mathrm{MO}}=12 \mathrm{~W}$

\subsection{Pattern 2:}

The highest temperature in PC is the CPU temperature, for this reason it must find ways to cool the processor. One of these ways is the changing the position of the inlet position to force the air near the processor, as shown in Fig. 4.b. In the pattern 2 and 3 the position of inlet were changed.

\subsubsection{The Effect of inlet Air Velocity:}

Fig. 8 shows the variation of temperatures of the components with inlet velocity at $\mathrm{P}_{\mathrm{CPU}}=16.5$ $\mathrm{W}, \mathrm{P}_{\mathrm{PSU}}=24 \mathrm{~W}, \mathrm{P}_{\mathrm{MO}}=12 \mathrm{~W}$. The temperature was decreased with increased in the inlet velocity, the slopes of decrease are similar for all components. The temperature of CPU is higher than the others, it various between $78.5^{\circ} \mathrm{C}$ at minimum inlet air velocity $1.2 \mathrm{~m} / \mathrm{s}$ to $75^{\circ} \mathrm{C}$ at $2.4 \mathrm{~m} / \mathrm{s}$. The $\mathrm{HS}$ temperature is the lowest one, it various between $34.3^{\circ} \mathrm{C}$ at minimum inlet air velocity $1.2 \mathrm{~m} / \mathrm{s}$ to $31.2^{\circ} \mathrm{C}$ at $2.4 \mathrm{~m} / \mathrm{s}$. The PSU1 temperature is higher than the PSU2 because position of inlet was moved away to be near HDD and CD, this prevent the air from moving quickly and the second inlet was less efficient than the second inlet in the pattern1.

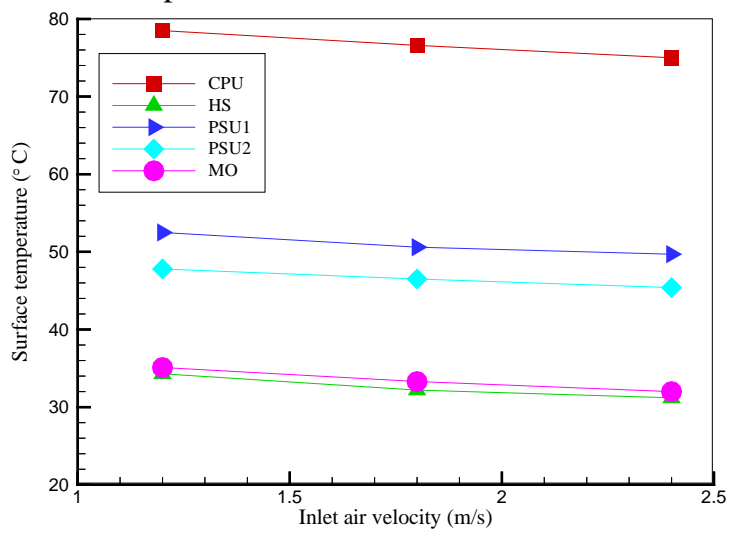

Figure 8: Variation of temperatures of the components with inlet velocity at $\mathrm{P}_{\mathrm{CPU}}=16.5 \mathrm{~W}$, $\mathrm{P}_{\mathrm{PSU}}=24 \mathrm{~W}, \mathrm{P}_{\mathrm{MO}}=12 \mathrm{~W}$, pattern 2 .

\subsection{Pattern 3:}

In this pattern, the first inlet was transferred to the region between the HHD and CD, and the second inlet was transferred to the place below the inlet two of pattern 1, as shown in Fig. 4.c.

\subsubsection{The Effect of inlet Air Velocity:}

Fig. 9 illustrates the variation of temperatures of the components with inlet velocity at $\mathrm{P}_{\mathrm{CPU}}=16.5 \mathrm{~W}, \mathrm{P}_{\mathrm{PSU}}=24 \mathrm{~W}, \mathrm{P}_{\mathrm{MO}}=12 \mathrm{~W}$. The temperature of CPU was the higher temperature, it various between $74.4^{\circ} \mathrm{C}$ at velocity $1.2 \mathrm{~m} / \mathrm{s}$ to $71.2{ }^{\circ} \mathrm{C}$ at $2.4 \mathrm{~m} / \mathrm{s}$. The HS temperature is the lowest one, it various between $34.1^{\circ} \mathrm{C}$ at minimum inlet air velocity $1.2 \mathrm{~m} / \mathrm{s}$ to $29.8^{\circ} \mathrm{C}$ at $2.4 \mathrm{~m} / \mathrm{s}$.

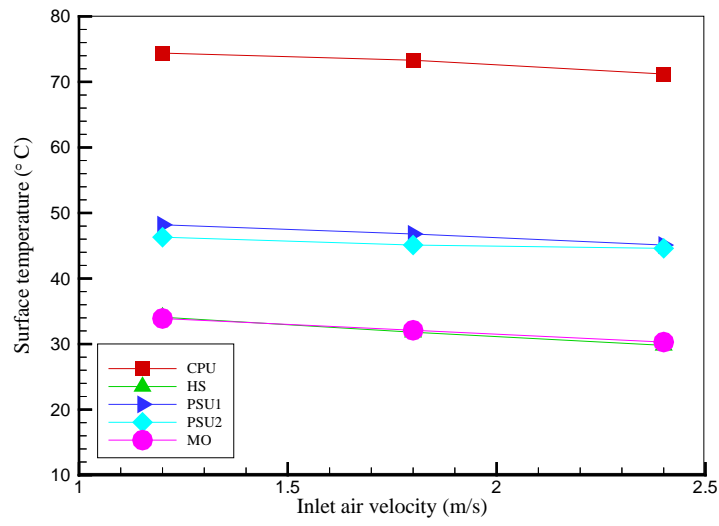

Figure 9: Variation of temperatures of the components with inlet velocity at $\mathrm{P}_{\mathrm{CPU}}=16.5 \mathrm{~W}$, $\mathrm{P}_{\mathrm{PSU}}=24 \mathrm{~W}, \mathrm{P}_{\mathrm{MO}}=12 \mathrm{~W}$, pattern 3

\subsection{The effect of patterns on the temperature difference of CPU:}

Fig. 10 explains the variation of CPU temperature difference with inlet velocity at different patterns, $\mathrm{P}_{\mathrm{CPU}}=16.5 \mathrm{~W}, \mathrm{P}_{\mathrm{PSU}}=24 \mathrm{~W}$, $\mathrm{P}_{\mathrm{MO}}=12 \mathrm{~W}$, the slopes of patterns 2 and 3 were similar and different from pattern 1 . As shown in figure, the pattern 1 was the best to reduce the 
CPU temperature, the temperature will increases in pattern 3 and increases more in pattern 2. The inlet position in pattern 1 forced the air on the CPU, while in pattern 3 it moved away for small distance and in pattern 2 it moved away to be in the area near $\mathrm{CD}$ and $\mathrm{HS}$. The maximum temperature difference in pattern 2 was $55.7^{\circ} \mathrm{C}$ and the minimum was $51.8^{\circ} \mathrm{C}$ in pattern 1 at 1.2 $\mathrm{m} / \mathrm{s}$ due to the place of inlet two made the flow near the CPU, the rate of temperature increase in the pattern 2 is (7\%). Fig. 11 shows the variation of CPU temperature with inlet velocity at different patterns, $\mathrm{P}_{\mathrm{CPU}}=12.5 \mathrm{~W}, \mathrm{P}_{\mathrm{PSU}}=16 \mathrm{~W}$, $\mathrm{P}_{\mathrm{MO}}=8 \mathrm{~W}$. the powers were used in this figure were lower than the Fig. 10, less temperature difference obtained and the same results, the pattern 1 was the best with lowest one temperature difference $39.9^{\circ} \mathrm{C}$, the highest temperature difference at pattern 2 was $41.6^{\circ} \mathrm{C}$ at $1.2 \mathrm{~m} / \mathrm{s}$, the rate of temperature increase in the pattern 2 is (4\%).

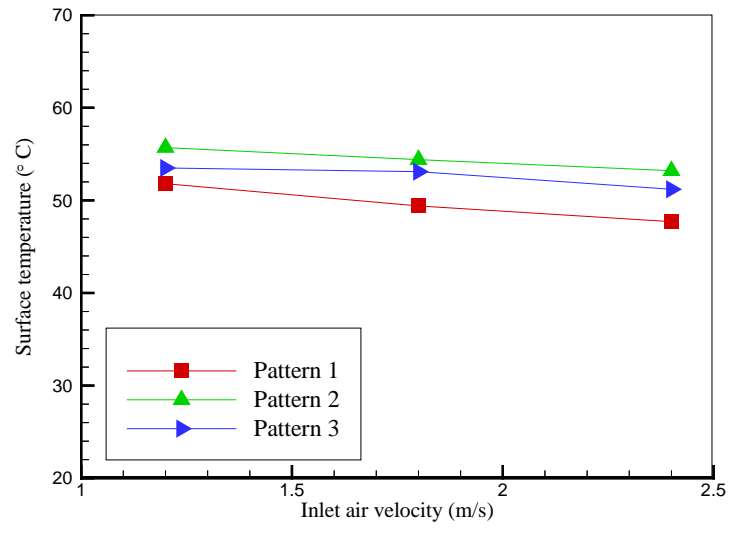

Figure 10: Variation of CPU temperature with inlet velocity at different patterns, $\mathrm{P}_{\mathrm{CPU}}=16.5 \mathrm{~W}$, $\mathrm{P}_{\mathrm{PSU}}=24 \mathrm{~W}, \mathrm{P}_{\mathrm{MO}}=12 \mathrm{~W}$

\section{Comparison between numerical and experimental results:}

Figs. 12 and 13 indicate the experimental and numerical results comparison for temperatures of CPU and MO with CPU power at $1.2 \mathrm{~m} / \mathrm{s}$. The numerical and experimental results were in good agreement and the behavior was similar. It was found that the experimental results are less than numerical results the due to the $\mathrm{Q}_{\text {Loss }}$ in experiments.

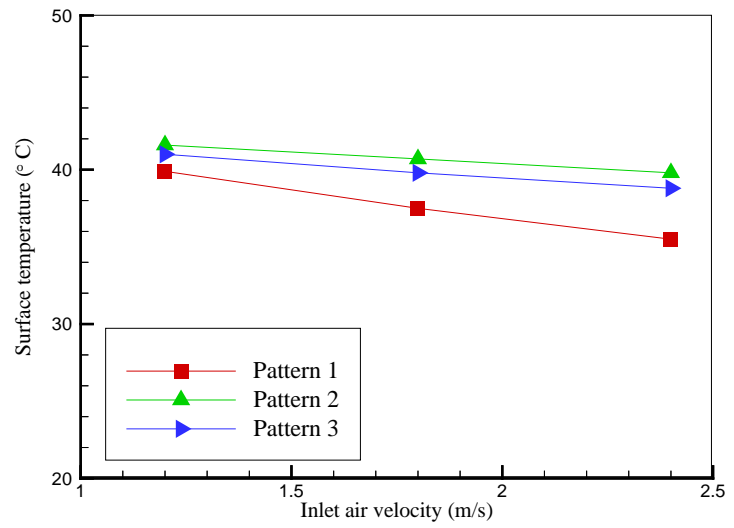

Figure 11: Variation of CPU temperature with inlet velocity at different patterns, $\mathrm{P}_{\mathrm{CPU}}=12.5 \mathrm{~W}$, $\mathrm{P}_{\mathrm{PSU}}=16 \mathrm{~W}, \mathrm{P}_{\mathrm{MO}}=8 \mathrm{~W}$

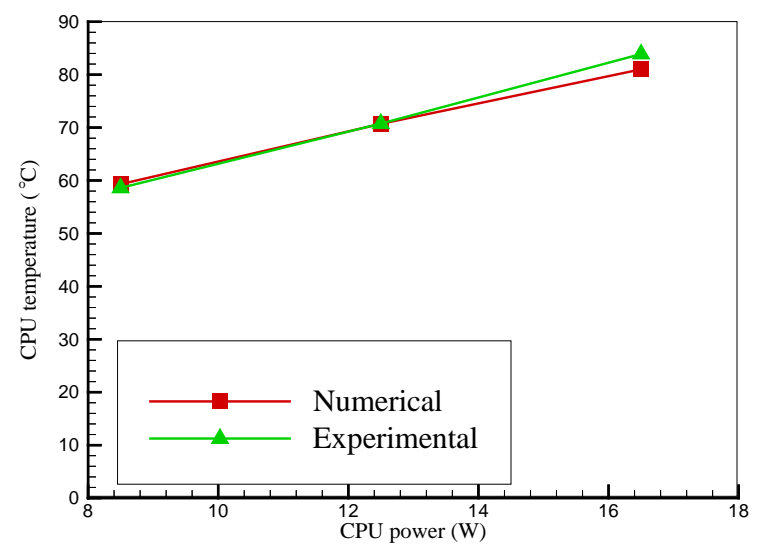

Figure 12: Comparison between the experimental and numerical results for CPU temperature with CPU power at $1.2 \mathrm{~m} / \mathrm{s}$

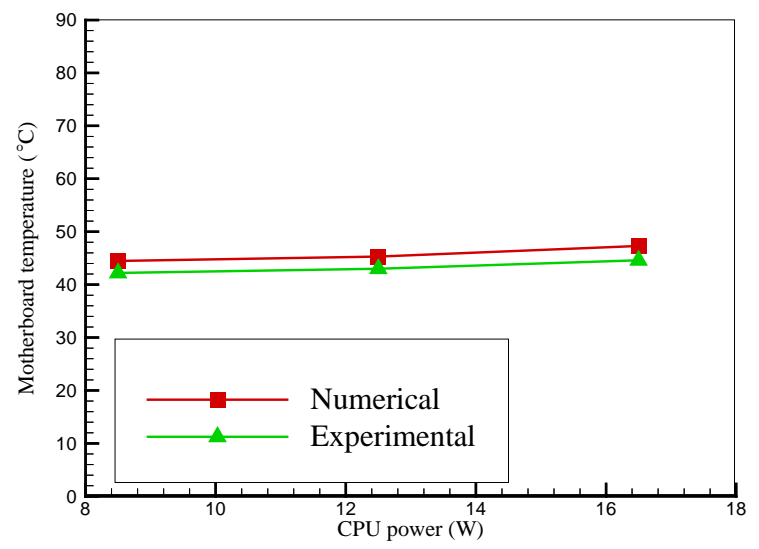

Figure 13: Comparison between the experimental and numerical results for MO temperature with CPU power at $1.2 \mathrm{~m} / \mathrm{s}$

\section{Numerical Results:}

\subsection{Effect of Power Dissipation:}

Fig. 14 shows the variation of temperatures with CPU power at $\mathrm{P}_{\mathrm{PSU}}=24 \mathrm{~W}, \mathrm{P}_{\mathrm{MO}}=12 \mathrm{~W}$, inlet velocity $1.2 \mathrm{~m} / \mathrm{s}$. In numerical results, the CPU power changed from $4.5 \mathrm{~W}$ to $18.5 \mathrm{~W}$, the temperature was increases with increases of CPU power, the slope of increase is similar for CPU 
and the slope was similar for PSU1, PSU2, HS and $\mathrm{MO}$, the reason for take $18.5 \mathrm{~W}$ instead of 20.5 is to keep the temperature close to allowable limits. In case of very low power of CPU the temperature was lower than the temperature of PSU faces.

\subsection{Effect of the Inlet Temperature:}

Fig. 15 shows the variation of temperatures with inlet temperature at $\mathrm{P}_{\mathrm{CPU}}=16.5 \mathrm{~W}, \mathrm{P}_{\mathrm{PSU}}=24 \mathrm{~W}$, $\mathrm{P}_{\mathrm{MO}}=12 \mathrm{~W}$, inlet velocity $1.2 \mathrm{~m} / \mathrm{s}, \mathrm{W}_{\mathrm{CPU}}=4 \mathrm{~m} / \mathrm{s}$, the slope was the same for all heat generation components, the inlet air temperature has a great effect on all temperatures inside the box $\left(\mathrm{T}_{\mathrm{CPU}}\right.$, $\mathrm{T}_{\mathrm{HS}}, \mathrm{T}_{\mathrm{MO}}, \mathrm{T}_{\mathrm{PSU} 1}, \mathrm{~T}_{\mathrm{PSU} 2}$ and $\mathrm{T}_{\text {air }}$ ).

\subsection{Effect of the CPU Fan:}

Fig. 16 illustrates the variation of CPU and HS temperatures with $\mathrm{W}_{\mathrm{CPU}}$ at $\mathrm{P}_{\mathrm{CPU}}=16.5 \mathrm{~W}, \mathrm{P}_{\mathrm{PSU}}=$ $24 \mathrm{~W}, \mathrm{P}_{\mathrm{MO}}=12 \mathrm{~W}$, inlet velocity $1.2 \mathrm{~m} / \mathrm{s}$, the CPU fan velocity at constant inlet temperature effect on the CPU and HS, the temperature of these components decrease with increases of the fan velocity. And there is no effect on other components at constant inlet velocity.

\subsection{Isotherm contours in P.C.:}

Fig. 17 shows $3 \mathrm{D}$ plots of the isotherm contours with different directions at $\mathrm{P}_{\mathrm{CPU}}=16.5 \mathrm{~W}, \mathrm{P}_{\mathrm{PSU}}=$ $24 \mathrm{~W}, \mathrm{P}_{\mathrm{MO}}=12 \mathrm{~W}, \mathrm{U}_{\text {in }}=\mathrm{W}_{\text {in }}=1.2 \mathrm{~m} / \mathrm{s}$, (a) $3 \mathrm{D}$, (b) $\mathrm{CPU}$ at $\mathrm{z}=20 \mathrm{~cm}$, (c) finned heat sink at $\mathrm{z}=17$ $\mathrm{cm}$, (d) motherboard at $\mathrm{z}=20 \mathrm{~cm}$, (e) PSU1 at $\mathrm{x}=$ $26 \mathrm{~cm}$, (f) PSU2 at $\mathrm{y}=31 \mathrm{~cm}$. The three dimensional plots show the temperature distribution inside the box. In $b, z=20 \mathrm{~cm}$, the red area shows the highest temperature in the box, it is CPU temperature. The internal volume temperature was nearly $83^{\circ} \mathrm{C}$. In $\mathrm{c}$, the HS temperature in finned position temperature will be greater than the others, in the middle area of the fin the temperature higher than the other area. And the temperatures reach about $40^{\circ} \mathrm{C}$ in the top of heat sink due to the position of outlet as shown in figure. In $\mathrm{d}$, the motherboard temperature at $\mathrm{z}=$ $20 \mathrm{~cm}$ was $47.3^{\circ} \mathrm{C}$; it was increases in area of CPU and near the position of outlet and decreases in the area at the bottom of the box. In e and $f$, the two faces of power supply were shown.

\subsection{Flow Field Distribution:}

Fig. 18 shows the flow field in P.C. at $\mathrm{P}_{\mathrm{CPU}}=16.5 \mathrm{~W}, \mathrm{P}_{\mathrm{PSU}}=24 \mathrm{~W}, \mathrm{P}_{\mathrm{MO}}=12 \mathrm{~W}, \mathrm{U}_{\text {in }}=\mathrm{W}_{\text {in }}$ $=1.2 \mathrm{~m} / \mathrm{s}$. In a, the figure shows the outlet openings. In b, the figure shows the flow field high processor fan velocities and inlet 1 . In c, five $\mathrm{x}$ surfaces are shown; the white areas represent the positions of HDD, CD and PSU. In d, five levels of y are shown

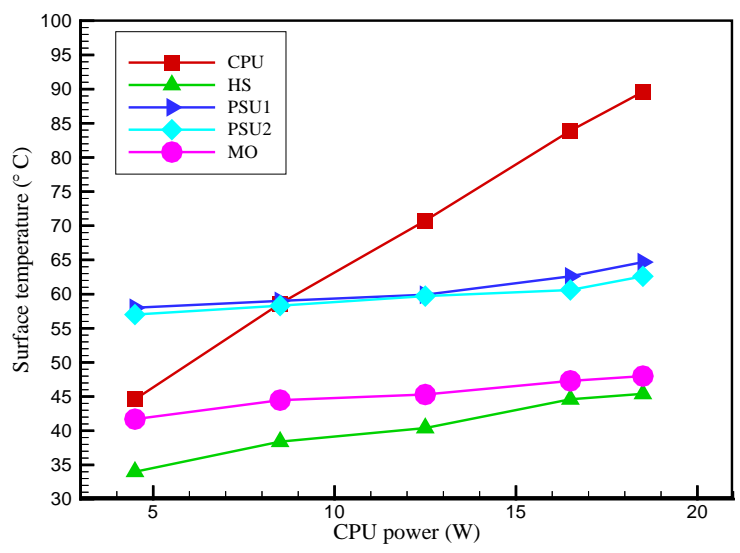

Figure 14: Variation of temperatures of the components with CPU power at $\mathrm{P}_{\mathrm{PSU}}=24 \mathrm{~W}, \mathrm{P}_{\mathrm{MO}}$ $=12 \mathrm{~W}$, inlet velocity $1.2 \mathrm{~m} / \mathrm{s}$

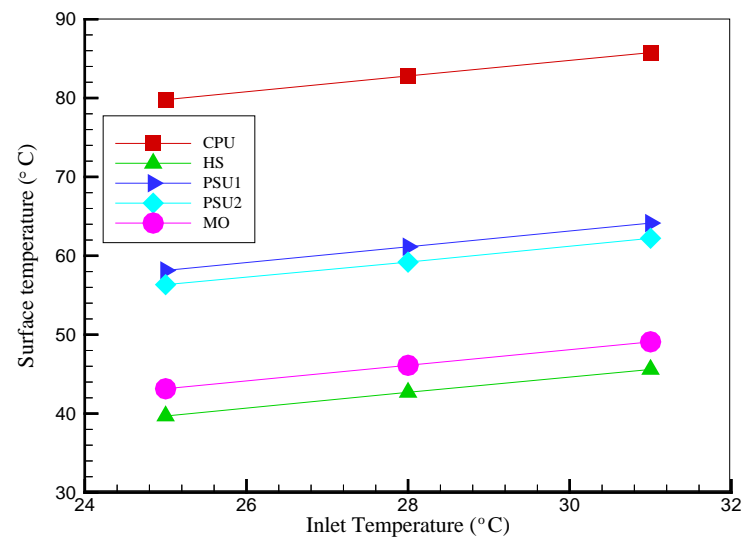

Figure 15: Variation of temperatures of the components with inlet air temperature at $\mathrm{P}_{\mathrm{CPU}}$ $=16.5 \mathrm{~W}, \mathrm{P}_{\mathrm{PSU}}=24 \mathrm{~W}, \mathrm{P}_{\mathrm{MO}}=12 \mathrm{~W}$, inlet velocity $1.2 \mathrm{~m} / \mathrm{s}, \mathrm{W}_{\mathrm{CPU}}=4 \mathrm{~m} / \mathrm{s}$

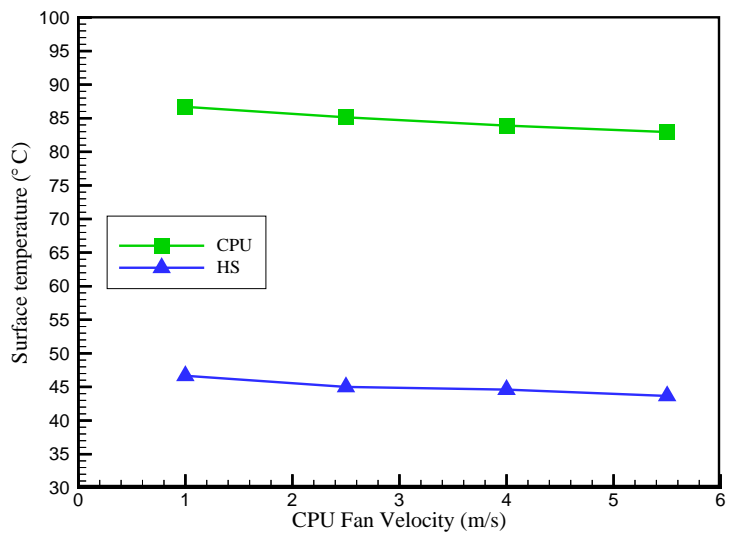

Figure 16: Variation of CPU and HS temperatures with $\mathrm{W}_{\mathrm{CPU}}$ at $\mathrm{P}_{\mathrm{CPU}}=16.5 \mathrm{~W}, \mathrm{P}_{\mathrm{PSU}}=$ $24 \mathrm{~W}, \mathrm{P}_{\mathrm{MO}}=12 \mathrm{~W}$, inlet velocity $1.2 \mathrm{~m} / \mathrm{s}$ 
(a)

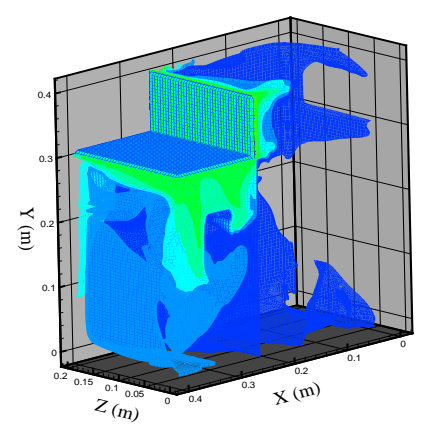

(d)

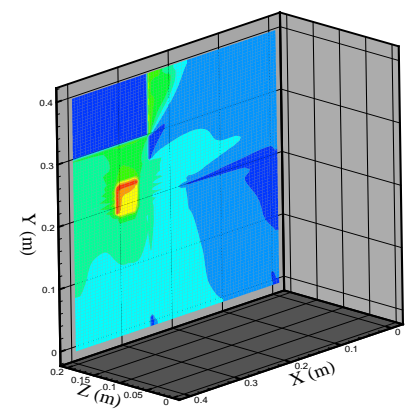

(b)
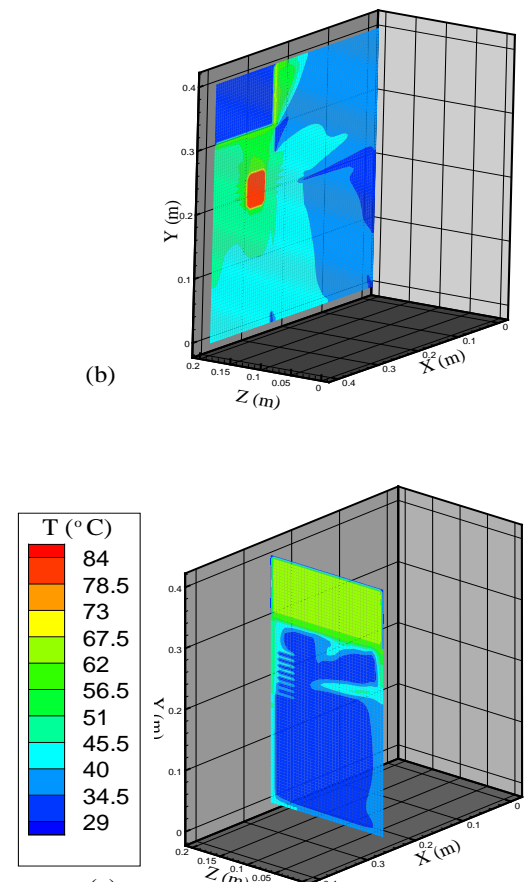

(e)

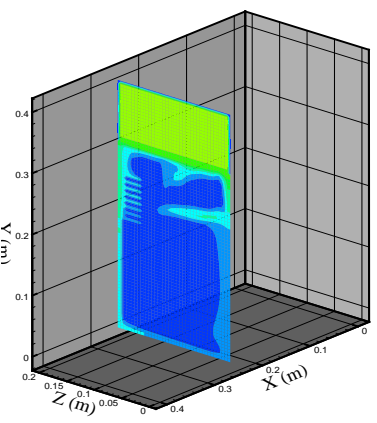

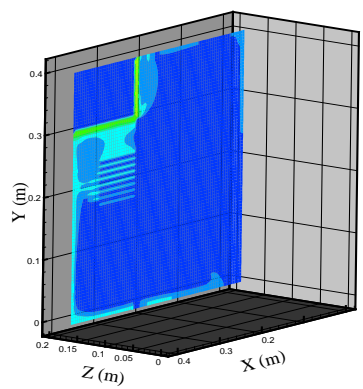

Figure 17: Isotherm contours at $\mathrm{P}_{\mathrm{CPU}}=16.5 \mathrm{~W}, \mathrm{P}_{\mathrm{PSU}}=24 \mathrm{~W}, \mathrm{P}_{\mathrm{MO}}=12 \mathrm{~W}, \mathrm{U}_{\mathrm{in}}=\mathrm{W}_{\text {in }}=1.2 \mathrm{~m} / \mathrm{s}$, (a) 3D, (b) $\mathrm{CPU} \mathrm{z}=20 \mathrm{~cm}$, (c) finned heat sink $\mathrm{z}=18 \mathrm{~cm}$, (d) motherboard $\mathrm{z}=20 \mathrm{~cm}$, (e) PSU1 $\mathrm{x}=26 \mathrm{~cm}$, (f) PSU2 $\mathrm{y}$ $=31 \mathrm{~cm}$

(a)

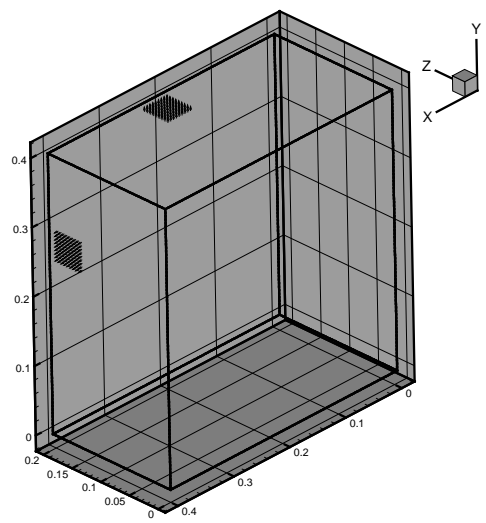

(c)

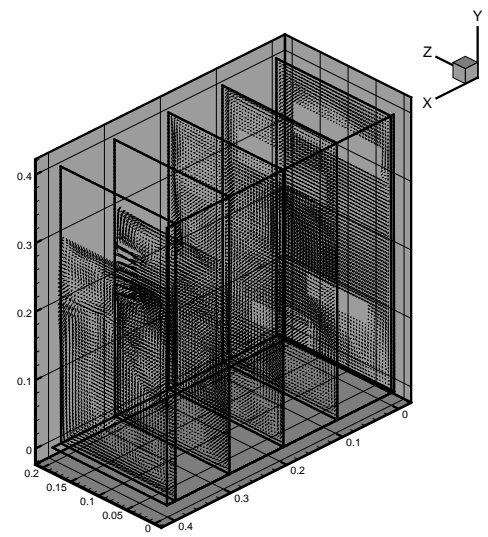

(b)

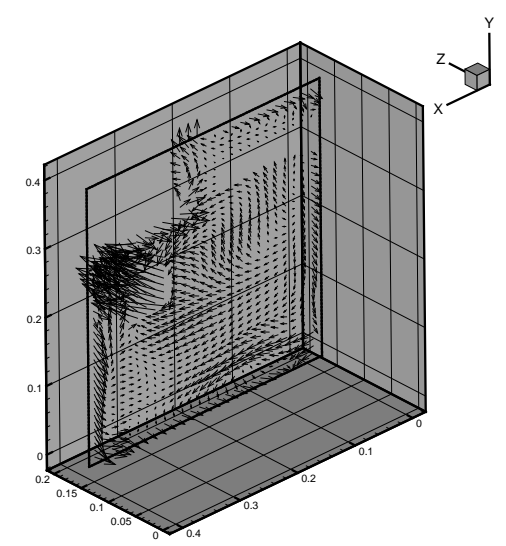

(d)

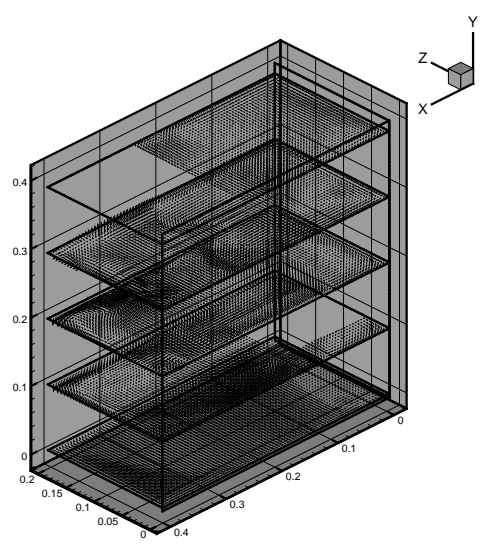

Figure 18: Flow field in P.C. $\left(\mathrm{P}_{\mathrm{CPU}}=16.5 \mathrm{~W}, \mathrm{P}_{\mathrm{PSU}}=24 \mathrm{~W}, \mathrm{P}_{\mathrm{MO}}=12 \mathrm{~W}, \mathrm{U}_{\mathrm{in}}=\mathrm{W}_{\mathrm{in}}=1.2 \mathrm{~m} / \mathrm{s}\right)$, a) outlet openings, b) $\mathrm{z}=0.1 \mathrm{~m}, \mathrm{c}$ ) di-fferent $\mathrm{x}$ surfaces, d) different $\mathrm{y}$ levels 


\section{Conclusions:}

The conclusions that can be drawn from the present study are:

1. The rate of temperature increase in the pattern 2 is $(7 \%)$ at $\mathrm{P}_{\mathrm{CPU}}=16.5 \mathrm{~W}, \mathrm{P}_{\mathrm{PSU}}=24 \mathrm{~W}$, $\mathrm{P}_{\mathrm{MO}}=12 \mathrm{~W}$. And (4\%) at $\mathrm{P}_{\mathrm{CPU}}=12.5 \mathrm{~W}, \mathrm{P}_{\mathrm{PSU}}$ $=16 \mathrm{~W}, \mathrm{P}_{\mathrm{MO}}=8 \mathrm{~W}$ as compared with pattern 1 .

2. The pattern 1 was the best in enhancing the cooling efficiency for the CPU.

3. The inlet temperature has great effect on the component temperatures.

4. The CPU fan velocity has effect on the cooling of the CPU and heat sink at constant inlet air velocity.

5. The temperature of the heat generation components decreases linearly with increases of inlet air velocity.

6 . The temperatures of the main components (PSU, motherboard) affected little by CPU power and vice versa.

7. The CPU temperature increases with CPU power linearly.

\section{References}

[1] J. Y. Chang, C. W. Yu, and R. L. Webb, "Identification of Minimum Air Flow Design for a Desktop Computer Using CFD Modeling" , Department of Mechanical and Nuclear Engineering, The Pennsylvania State University, University Park, PA 16802-1413, pp.330-338, 2000.

[2] J.S. Chiang, S.H. Chuang, Y.K. Wu and H.J. Lee, "Numerical Simulation of Heat Transfer in a Desktop Computer with Heat-Generating Components", International Communications in Heat and Mass Transfer, Vol. 32, pp. 184-191, (2005).
[3] M. Anandakrishnan and C. Balaji, "CFD Simulations of Thermal and Flow Fields inside a Desktop Personal Computer Cabin with MultiCore Processors" , Engineering Applications of Computational Fluid Mechanics, Vol.3 No.2 pp.277-288, 2009.

[4] E. Ozturk and I. Tari, "Forced Air Cooling of CPUs with Heat Sinks: A Numerical Study" , IEEE Transactions on Components and Packaging Technologies, Vol. 31, No. 3, September, 2008.

[5] R. Mohan and P. Govindarajan, "Thermal Analysis of CPU with Variable Heat Sink Base Plate Thickness using CFD" , International Journal of the Computer, the Internet and Management, Vol. 18, No.1 , pp. 27-36, 2010.

[6] S. K.Wang, J.H.Hu and C.H. Kuo, "Passive Enhancement of Heat Dissipation of Desktop computer Chassis" , Engineering Applacations of Compotational Fluid Dynamics, Vol. 4, No.1, pp.139-149, 2010.

[7] L. Maode, Q. Cong and Z. Zhisong, "Numerical Analysis of Temperature Field on the Desktop Computer Motherboard" , Applied Mechanics and Materials Vols. 644-650, pp.1531-1534, 2014.

[8] H. B. Awbi," Ventilation of Buildings", London, 2003.

[9] H. K. Versteeg, and W. Malalsekera, "An Introduction to Computational Fluid DynamicsThe Finite Volume Method”, Longman group Ltd., 1996.

[10] B. K. Dutta "Heat Transfer, Principles and Applications”, Prentice Hall of India 2006.

[11] J. P. Holman, "Heat Transfer", McGraw-Hill, Inc. 2004.

[12] G. E. Myers, "Analytical Methods in Conduction Heat Transfer” McGraw-Hill, Inc., 1971.

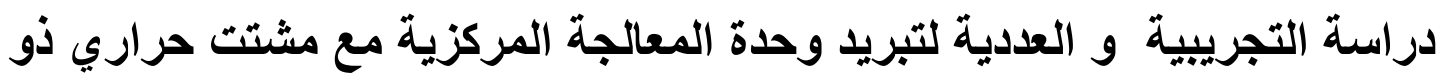

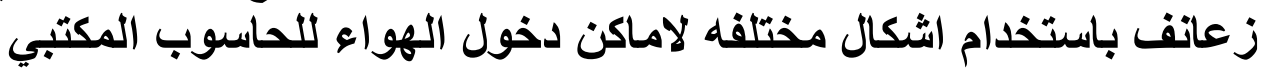

$$
\begin{aligned}
& \text { قسم الهندسة هادي كردية الكروميكانيكية } \\
& \text { قسم الهندسة الكهروميكنانيكية علية التكنية } \\
& \text { قسم الهندسة الكهروميكانيل جليكية }
\end{aligned}
$$

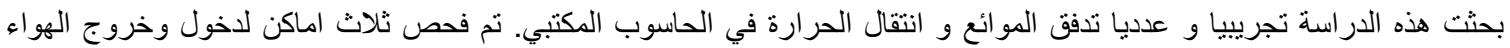

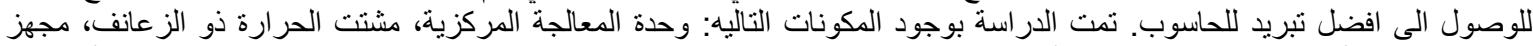

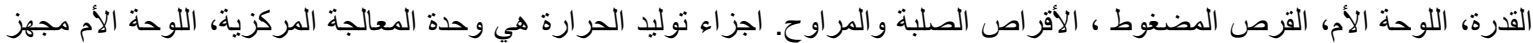

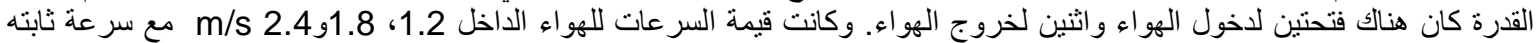

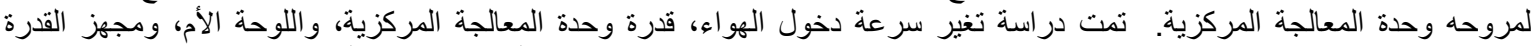

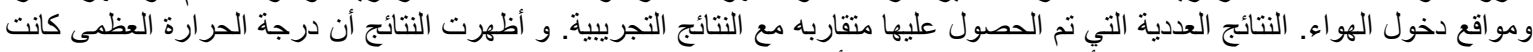

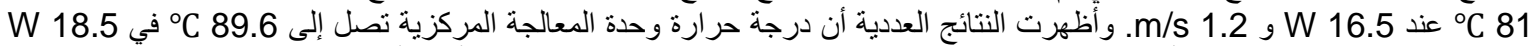

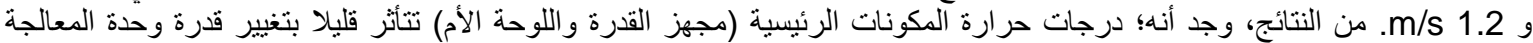

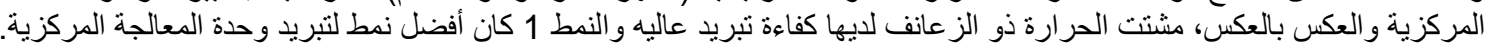

